\title{
CORRECTIONS
}

\section{Is Movember misleading men?}

This Observations article by Margaret McCartney incorrectly states in its seventh paragraph that Movember donated $£ 6.5 \mathrm{~m}$ ( $€ 8 \mathrm{~m} ; \$ 10.4 \mathrm{~m})$ to the Institute of Cancer Research (BMJ 2012;345:e8046, doi:10.1136/bmj.e8046). This figure was given as the result of a misunderstanding between the author and the Institute of Cancer Research. The Institute of Cancer Research has informed us that the amount it has received or that has been pledged to it currently stands at about $£ 1.5 \mathrm{~m}$ (not $£ 6.5 \mathrm{~m}$ ). It is planning to bid for the remaining $£ 5 \mathrm{~m}$ over five years to become a Movember Centre of Excellence, but there is no guarantee that it will secure this funding.

Cite this as: BMJ 2012;345:e8200

๑ BMJ Publishing Group Ltd 2012 